\title{
POLA KOMUNIKASI KEAGAMAAN DALAM MEMBENTUK KEPRIBADIAN ANAK
}

\author{
Imam Subqi \\ Dosen Pengembangan Masyarakat Islam IAIN Salatiga \\ imamsubqi@gmail.com
}

\begin{abstract}
This article specifically discusses the pattern of Islamic construction which is expected to make up the individual identity and marks them as Muslim, both are shown in their behavior. Behavior looks like walking, eating, drinking, communicating with teachers, parents, friends and others. While the inner behavior proposed by Frank Burton Cheyne is sincere, don't envy and other commendable attitudes rising from their inner feeling. From variety of thoughts above, the construction of the Islamic religion, addressed to children will be able to provide a steady view of life based on the values of Islam, and they were also able to get used to think, behave according to the norms of Islam or personality in accordance with the teachings of Islam although they have a different default factors.
\end{abstract}

Keywords: Communacation, Religious, Behavior

\begin{abstract}
Abstrak
Artikel ini secara spesifik membahas tentang pola keberagamaan Islam yang diharapkan mampu membenahi kepribadian individu dan menandai mereka sebagai Muslim, dua hal tersebut nampak dalam tingkah laku mereka. Tingkah laku seperti berjalan, makan, minum, hubungan dengan guru, orang tua, teman-teman, dan yang lainya. Sedangkan menurut Frank Burton Cheyne memaknai tingkah laku batiniah sebagai keiklasan, tidak iri, dan sikap terpuji lain yang muncul dari dalam perasaan mereka. Dari berbagai pendapat diatas, pengajaran agama islam yang diberikan kepada anak-anak mampu memberikan pandangan hidup yang kuat berdasarkan nilai keislaman dan mereka mampu terbiasa berfikir, dan bertindak berdasarkan norma keislaman atau pribadi berdasarkan ajaran islam meskipun mereka mempunyai faktor kesulitan yang berbeda.
\end{abstract}

Kata Kunci: Komunikasi, Agama, Keperibadian

\section{Pendahuluan}

Pada hakekatnya manusia adalah makhluk yang dilahirkan dalam keadaan lemah dan tidak berdaya, namun dengan demikian ia telah mempunyai potensi bawaan yang bersifat laten. Dalam perkembangannya manusia dipengaruhi oleh pembawaan dan lingkungan, dan salah satu sifat hakiki manusia adalah mencapai kebahagiaan, dan untuk mencapai kebahagiaan itu manusia membutuhkan agama. (Ismail, 2001:219) Sejak dilahirkan anak membawa fitrah beragama, fitrah ini baru berfungsi setelah melalui proses bimbingan dan latihan. Fitrah dapat bermakna potensi untuk beragama, keinginan beragama, juga potensi untuk tidak beragama. Kecendrungan potensi itu tidak akan berubah-ubah oleh Allah, artinya memang demikian manusia diciptakan. Dengan 
Inject, Interdisciplinary Journal of Communication, Vol. 1, No. 2, Desember 2016:165-180

demikian, memang sejak lahir sudah membawa potensi untuk beragama. (Ismail, 2001:220)

Hal ini pelaksanaan ajaran-ajaran agama, setiap pemeluk agama Islam diharapkan dapat melaksanakan atau mengamalkan ajaran-ajaran agamanya dalam kehidupan sehari-hari seperti adanya kewajiban untuk menjalankan ibadah sholat, puasa, zakat, haji. Bagi umat Islam seluruh kehidupannya untuk beribadah kepada Allah. Hal ini sesuai tujuan diciptakannya manusia yang merupakan tujuan pokok dalam pendidikan agama Islam, manusia itu diciptakan tak lain hanyalah untuk beribadah atau mengabdi kepada Allah.

Mengingat pentingnya peranan agama tersebut maka agama perlu diketahui, digali, dipahami serta diamalkan oleh setiap pemeluk agama. Hal ini khususnya pemeluk agama Islam, sehingga nantinya akan benar-benar menjadi milik dan kepribadian dalam kehidupan sehari-hari. Salah satu usaha untuk mencapai hal tersebut dengan melalui pendidikan yaitu pendidikan agama Islam. Melalui pendidikan manusia disuruh untuk berfikir, menggunakan akal sesuai dengan fungsinya guna mencapai pengetahuan yang benar. Adapun cara pendidikan untuk menanamkan dalam diri anak-anak nilai-nilai agama dan budaya islami yang benar, pendidik juga harus mengajarkan anak-anaknya moral Islami dan memberitahukan kepada mereka ketentuan-ketentuan syariat agama. (Zuhaili, 2002:64) Masyarakat juga kerkewajiban memberikan pendidikan bagi anggotanya atau biasa disebut pendidikan yang bersifat informal, karena di masyarakatlah anak-anak melihat, meniru dan mencontoh apa yang dilakukan oleh orang-orang disekitarnya. Jika contoh yang diberikan oleh masyarakat itu baik dan positif, maka generasi mudanya akan terpengaruh berperilaku dan berkepribadian baik pula. Memang diakui bahwa pengaruh masyarakat berperan besar dalam pembentukan kepribadian anak. (Wahjoeutomo, 1979:42) Disamping masyarakat, sekolah-sekolah dan lembaga sosial yang memberikan pendidikan harus memperhatikan pembinaan agama pada anak didiknya. Agama Islam bukan sekedar puasa, zakat atau haji, melainkan juga berisi norma-norma dan nilai-nilai untuk berinteraksi dengan lingkungan sosialnya baik orang tua, masyarakat dan alam sekitar.

\section{Makna Pembinaan Agama Islam}


Menurut Kamus Besar Bahasa Indonesia (1990:37), bahwa pembinaan berarti usaha, tindakan dan kegiatan yang diadakan secara berdaya guna dan berhasil guna untuk memperoleh hasil yang lebih baik. Pembinaan juga dapat berarti suatu kegiatan yang mempertahankan dan menyempurnakan apa yang telah ada sesuai dengan yang diharapkan. (Soetopo, 1982:43)

Definisi tersebut dapat disimpulkan bahwa pembinaan adalah suatu usaha atau kegiatan yang dilakukan untuk meningkatkan apa yang sudah ada kepada yang lebih baik (sempurna), baik dengan melalui pemeliharaan dan bimbingan terhadap apa yang sudah ada, yang sudah dimiliki, serta dengan mendapatkan hal yang belum dimilikinya yaitu pengetahuan dan kecakapan yang baru.

Pembangunan di bidang agama diarahkan agar semakin tertata kehidupan beragama yang harmonis, semarak dan mendalam. Serta ditujukan pada peningkatan kualitas keimanan dan ketakwaan terhadap Tuhan Yang Maha Esa, terpeliharanya kemantapan kerukunan hidup umat beragama dan bermasayarakat dan berkualitas dalam meningkatkan kesadaran dan peran serta akan tanggung jawab terhadap perkembangan akhlak serta untuk secara bersama-sama memperkukuh kesadaran spiritual, moral dan etika bangsa dalam pelaksanaan pembangunan nasional, peningkatan pelayanan, sarana dan prasarana kehidupan beragama. Dimaksudkan untuk lebih memperdalam pemahaman dan peningkatan pengalaman ajaran dan nilai-nilai agama untuk membentuk akhlak mulia, sehingga mampu menjawab tantangan masa depan.

Peningkatan kualitas keimanan dan ketakwaan Terhadap Tuhan Yang Maha Esa diarahkan agar dapat menjiwai kehidupan bermasyarakat, berbangsa dan bernegara yang dilaksanakan melalui pemahaman dan pengamalan nilai-nilai spiritual, moral, dan etik keagamaan, sehingga terbentuk sikap batin dan sikap lahir yang setia. (Shaleh, 2000:204)

\section{Pengertian dan Pengamalan Keagamaan}

Agama berasal dari Bahasa Sansekerta yang artinya tidak kacau, diambil dari dua suku kata "a" berarti tidak dan "gama" berarti kacau, secara lengkapnya agama ialah peraturan yang mengatur manusia agar tidak kacau. (Kahmad, 2000:21) Agama adalah aturan dari Tuhan Yang Maha Esa, untuk petunjuk kepada manusia agar dapat selamat dan sejahtera atau bahagia hidupnya di dunia dan akhirat dengan petunjuk-petunjuk 
Inject, Interdisciplinary Journal of Communication, Vol. 1, No. 2, Desember 2016:165-180

serta pekerjaan nabi-nabi beserta kitab-kitab-Nya. (Marimba, 1989:128) Jadi agama adalah merupakan aturan-aturan atau perundang-undangan yang datangnya dari Tuhan diturunkan kepada manusia sebagai pedoman hidup di dunia akherat agar memperoleh kebahagiaan di dunia dan akherat kelak. Agama sebagai refleksi atas cara beragama tidak hanya terbatas pada kepercayaan saja, tetapi juga merefleksi dalam perwujudanperwujudan tindakan kolektifitas umat, bangunan perubahan. Perwujudan-perwujudan tersebut keluar sebagai bentuk dari pengungkapan cara beragama sehingga agama dalam arti umum dapat diuraikan menjadi beberapa unsur atau dimensi religiusitas.

Agama yang dianggap sebagai suatu jalan hidup bagi manusia (way of life) menuntun agar hidupnya tidak kacau. Agama berfungsi untuk memelihara integritas manusia dalam membina hubungan dengan Tuhan dan hubungan dengan sesama manusia dan dengan alam yang mengitarinya. Oleh sebab itu, agama pada dasarnya berfungsi sebagai alat pengatur untuk terwujudnya integritas hidup manusia dalam hubungan dengan Tuhan dan hubungan dengan alam yang mengitarinya.

Sedangkan pengamalan berasal dari kata amal yang artinya perbuatan baik atau buruk yang mendapat awalan "pe" dan akhiran "an", yang berarti proses. Jadi pengamalan berarti proses perbuatan, melaksanakan, pelaksanaan, penerapan. Agama sebagai refleksi atas cara beragama tidak hanya terbatas pada kepercayaan saja, tetapi juga merefleksi dalam perwujudan-perwujudan tindakan kolektivitas umat. Perwujudanperwujudan tersebut keluar sebagai bentuk dari pengungkapan cara beragama, sehingga agama dalam arti umum dapat diuraikan menjadi beberapa unsur, atau dimensi religiusitas yaitu emosi keagamaan, sistem kepercayaan, sistem upacara keagamaan dan umat atau kelompok-kelompok keagamaan. (Kadir, 2002:4) Pengamalan keagamaan adalah mengamalkan atau mengaplikasikan ajaran-ajaran agama Islam dalam kehidupan sehari-hari seperti shalat, puasa, zakat, haji, pergaulan hidup dalam masyarakat dan yang lainnya.

\section{Dasar dan Tujuan Pembinaan Keagamaan}

Dasar pembinaan adalah ajaran-ajaran yang ada dalam al-Quran dan al-hadits yang semua telah difirmankan oleh Allah SWT dan telah disabdakan oleh Rasulullah SAW, sebagaimana tertulis di dalam al-Quran. Q.S. Ali Imran : 104. Artinya: "Dan hendaklah ada diantara kamu segolongan umat yang menyeru kepada kebajikan, menyuruh kepada 
Imam Subqi, Pola Komunikasi Keagamaan Dalam Membentuk...

yang makruf dan mencegah dari yang mungkar, merekalah orang-orang yang beruntung".

Demikian orang yang beriman harus menyelamatkan dirinya dan warganya sesama manusia dari kerusakan budi pekerti serta untuk mencapai kebahagiaan yang berimbang antara dunia akherat dengan cara memberi bimbingan agar mereka mempunyai budi pekerti yang luhur segala perbuatannya berpedoman pada ajaran Islam. Adapun tujuan dari pembinaan kegamaan ini tidak dapat terlepas dari tujuan hidup manusia yakni untuk mencapai kebahagiaan di dunia dan akherat. Sebagaimana firman Allah dalam Surat al-Qashash: 77. Artinya: "Dan carilah kepada apa yang telah dianugerahkan Allah kepadamu (kebahagiaan) negeri akherat dan janganlah kamu melupakan kebahagiaan dari kenikmatan duniawi dan berbuat baiklah (kepada orang lain) sebagaimana Allah telah berbuat baik kepadamu dan janganlah kamu berbuat kerusakan di muka bumi. Sesungguhnya Allah tidak menyukai orang-orang yang berbuat kerusakan".

Merujuk pada pengertian pembinaan di atas dapat disimpulkan bahwa tujuan dari pembinaan adalah agar tercapainya kesempurnaan, artinya untuk mengadakan peningkatan dari yang sebelumnya. Bila sebelumnya kurang baik dan tidak sesuai dengan yang diinginkan. Dengan demikian tujuan dari pembinaan keagamaan adalah mewujudkan manusia yang mempercayai dan menjalankan ajaran agama Islam dengan sepenuhnya.

Status ini mengimplikasikan bahwa manusia secara potensial memiliki sejumlah kemampuan yang diperlukan untuk bertindak sesuai dengan ketentuan Tuhan, sebagai khalifah. Manusia juga mengemban fungsi rububiyah Tuhan terhadap alam semesta termasuk diri manusia sendiri. (Mukhtar, 2001:29) Sesuai dengan ajaran agama maka pendidikan Islam bukan saja mengajarkan ilmu-ilmu sebagai materi, atau keterampilan sebagai kegiatan jasmani semata, melainkan mengaitkannya semuanya itu dengan kerangka praktek (amaliyah) yang bermuatan nilai dan moral. Hal ini mengimplikasikan bahwa tujuan penanaman agama Islam tidak hanya terbatas pada pencapaian materiil untuk kepentingan dirinya melainkan meniscayakan keterpaduan antara aspek jasmaniah (lahiriyah) dan rohani (batiniyah), antara kehidupan dunia dan akhirat, dan antara kepentingan individual dan kepentingan kolektif, dan antara kedudukannya sebagai khalifah (wakil Allah) dan tugas sebagai abdun (hamba Allah), karena pembinaan agama ini ditujukan kepada Ibu rumah tangga melalui kegiatan Muslimat yang nantinya akan 
Inject, Interdisciplinary Journal of Communication, Vol. 1, No. 2, Desember 2016:165-180

berperan dalam pembinaan generasi muda pada umumnya dan kehidupan moral, dan agama khususnya, sangat penting.

Jika kembali kepada peranan wanita dalam pembinaan generasi muda tadi, akan tampak bahwa wanita mempunyai fungsi yang sangat penting, karena wanita masuk ke segala segi kehidupan generasi muda sebagai ibu, wanita mempunyai fungsi sebagai pembina pertama bagi pribadi anaknya, pendidikan dan perlakuannya menentukan kesehatan jiwa anaknya di kemudian hari (Darajat, 1996:134). Oleh sebab itu, peranan wanita dalam pembinaan generasi muda secara umum, terutama dalam kehidupan moral dan agama sangat penting. Agar dapat menunaikan tugas dan fungsinya yang sangat penting itu, wanita (ibu dan istri) perlu dipersiapkan dengan baik, melalui berbagai cara, baik pendidikan formal yaitu semenjak mereka masih muda dan belum menikah melalui kegiatan-kegiatan pengajian.

\section{Metode Komunikasi dan Pembinaan Keagamaan pada Masyarakat}

Metode berasal dari dua kata, yaitu meta dan hodos, meta berarti melalui dan hodos berarti jalan atau cara. Jadi metode mengandung pengertian suatu jalan atau cara yang dilalui untuk mencapai suatu tujuan. Dari sisi pendidikan metode berarti ilmu yang membicarakan cara atau teknik menyajikan bahan pelajaran terhadap siswa agar tercapai tujuan yang inginkan secara efektif dan efesien (Nata,1997:91).

Bilamana dikaitkan dengan pembinaan agama Islam, maka batasannya terletak pada metode atau teknik apakah yang lebih cocok digunakan dalam penyampaian materi agama tersebut agar tujuan pembelajaran yang ditetapkan dapat tercapai secara efektif dan efesien. Dengan demikian dapat kita simpulkan bahwa metode pengajaran agama Islam adalah cara yang tepat dan cepat. Inilah yang sering diungkapkan dalam ungkapan efektif dan efesien. Kalau begitu metode pengajaran agama Islam ialah cara yang paling efektif dan efesien dalam mengajarkan agama Islam (Tafsir,1995:9).

Metode yang digunakan dalam pembinaan keagamaan masyarakat sama halnya dengan pendidikan agama Islam. Meskipun demikian tidak semua metode mngajar di dalam kelas (pendidikan formal) dapat digunakan diluar kelas (pendidikan non formal) dalam hal ini pengajian muslimat. Sebuah metode yang akan digunakan hendaklah jelas artinya yaitu menuju ke jalan Tuhan. Sedangkan metode yang sering digunakan adalah: Pertama metode ceramah, suatu cara penyampaian bahan secara lisan oleh guru. Di sini 
Imam Subqi, Pola Komunikasi Keagamaan Dalam Membentuk...

guru memberikan uraian atau penjelasan kepada sejumlah murid pada waktu tertentu (waktuya terbatas) dan tempat tetapi pula untuk memberikan pengertian terhadap suatu masalah. Dalam metode ceramah ini murid duduk, melihat dan mendengarkan serta percaya bahwa apa yang dicermahkan guru adalah benar, murid mengutip ikhtisar ceramah semampu murid itu sendiri dan menghapalkannya tanpa penyelidikan lebih lanjut oleh guru yang bersangkutan.

Kedua metode tanya jawab, penyampaian pesan pengajaran dengan cara mengajukan pertanyaan-pertanyaan dan siswa memberikan jawaban atau sebaliknya siswa diberi kesempatan untuk bertanya dan guru menjawab (Usman, 2002:1). Metode ini dapat dikembangkan ketrampilan/kemampuan mengamati, menginterpretasi, mengklasifikasikan, menarik kesimpulan, menerapkan dan mengkomunikasikan (Shaleh, 2000:68).

Ketiga metode kisah, mengandung arti suatu cara dalam menyampaikan materi pelajaran dengan menuturkan secara kronologis tentang bagaimana terjadinya sesuatu hal yang baik yang sebenarnya terjadi ataupun hanya rekaan saja (Arif, 2002:160). Metode ini mempunyai pengaruh tersendiri bagi jiwa dan akal, dengan argumentasiargumentasi yang logis dan rasionalis. Al-Quran memakai metode ini di beberapa tempat, lebih-lebih dalam berita-berita tentang para rasul dan kaumnya. Allah telah menceritakan kepada Rasulullah SAW dan cerita-cerita yang paling baik tentang kejadian-kejadian yang baik, sebagai cermin bagi umat manusia (Ulwan,1999:222).

Keempat metode nasehat, digunakan dengan maksud manimbulkan kesadaran pada orang yang dinasehati agar mau insaf melaksanakan ketentuan hukum atau ajaran yang dibenarkan (Nata, 1997:99). Metode ini pada umumnya ditujukan kepada mereka yang melanggar peraturan, tetapi jarang terjadi. Biasanya lebih sering digunakan untuk memberi kesadaran atau kewajiban yang telah dikorbankan. Agar lebih efektif. Penggunaan metode ini sebaiknya disertai dengan panutan atau teladan dari orang-orang yang memberi nasehat. Metode ini cukup berhasil dalam pembentukan akidah anak dan mempersiapkannya baik secara moral, emosional maupun sosial adalah pendidikan anak dengan petuah dan memberikan kepadanya nasehat-nasehat.

Bila petuah yang tulus dan nasehat yang berpengaruh, jika memasuki jiwa yang bening, hati terbuka, akal yang jernih dan berpikir, maka dengan cepat mendapat respon yang baik dan meningggalkan bekas yang sangat dalam, dengan cepat akan tunduk 
Inject, Interdisciplinary Journal of Communication, Vol. 1, No. 2, Desember 2016:165-180

kepada kebenaran dan menerima hidayah Allah yang diturunkan. Selain metode-metode tersebut di atas masih banyak lagi metode-metode lainnya. Namun di dalam menentukan metode yang kan digunakan hendaknya disesuaikan dengan situasi dimana pembinaan keagamaan dilaksankaan dan harus disesuaikan dengan tujuan yang ingin dicapai.

\section{Materi dalam Pembinaan Keagamaan pada Masyarakat}

Agama Islam sebagai agama terakhir yang dibawa oleh Nabi Muhammad SAW. Sebagai utusan terakhir yang berfungsi sebagai rahmatan lil alamin yaitu rahmat dan nikmat bagi seluruh alam, utamanya bagi kehidupan manusia, sebagai risalah yang terakhir Islam memiliki nilai universal dan eternal, sesuai dengan kebutuhan manusia. Islam memiliki bentuk ajaran yang lebih sempurna dibanding ajaran sebelumnya.

Pada hakikatnya agama Islam tidak lain adalah sebagai pemenuhan janji Tuhan bahwa akan memberikan petunjuk kepada manusia tentang bagaimana seharusnya manusia ini menempuh hidupnya secara wajar sehingga sejalan dan serasi dengan alam sekitarnya. Untuk memenuhi semua kebutuhan hidup manusia, Islam memiliki tiga inti ajaran yang merupakan inti dasar ajaran Islam meliputi aqidah, syariah dan akhlak. Dasar-dasar ini terpadu menjadi satu dan merupakan bagian yang tak terpisahkan satu dengan yang lain (Zuhairini,1995:42). Secara garis besar ketiga materi tersebut dapat dijabarkan sekaligus menjadikan sifat universalitas dan eternalitas Islam adalah sebagai berikut: Pertama, materi aqidah (tauhid). Membahas tentang kepercayaan kepada keesaan Allah SWT dan segala sesuatu yang berhubungan dengan keesaan Allah SWT itu (rukun iman), berdasarkan dalil naqliyah maupun aqliyah menurut kemampuan akal manusia yang dilandasi dengan iman (Matdawam, 1995:6). Pada prinsipnya di dalam aqidah yang terpenting bukanlah pengetahuan tentang Allah, tetapi hubungan antara seseorang hamba dengan Allah yang akan timbul sikap dedikasi, rasa pengabdian, dan penyerahan diri. Islam merupakan anak tangga yang terakhir dan tertinggi karena ketegasannya tentang monotheisme yang mulus.

Doktrin tauhid (aqidah) bagi kehidupan manusia menjadi sumber kehidupan jiwa dan pendidikan kemanusiaan yang tinggi. Tauhid akan mendidik jiwa manusia untuk mengikhlaskan seluruh hidup dan kehidupannya kepada Allah semata. Tujuan hidupnya ialah Allah dan harapan yang dikejarnya ialah keridhaan Allah. Dengan demikian membawa konsekuensi pembinaan karakter yang agung, menjadi manusia yang suci, 
jujur dan teguh memegang amanah. Tauhid akan membebaskan manusia dari perasaan keluh kesah, bingung menghadapi persoalan hidup dan akan bebas dari rasa putus asa. Jadi tauhid memberikan kebahagiaan hakiki pada manusia di dunia dan kebahagiaan abadi di akhirat kelak (Razak, 1998:42).

Kedua, kata Syariah secara etimologi berarti jalan, sementara secara terminologi (qaidah syariah islamiyah) berarti suatu sistem norma ilahiah yang mengatur hubungan antara manusia dengan Tuhan, sesama manusia dan hubungan antar manusia dengan alam sekitarnya (Ansori, 1989:90). Menurut Zuhairini, (2007:49) syariah berpusat pada dua segi yaitu segi hubungan manusia dengan Tuhannya yang bersifat ibadah dan segi hubungan manusia dengan sesamanya dan kemaslahatan hidupnya disebut muamalah. Keduanya sangat erat kaitannya dan tidak dapat dipisahkan antara satu dengan lainnya, dalam arti kedua-duanya harus bernilai ibadah dengan maksud dan tujuan manusia diciptakan, maka ibadah dan muamalah, dalam pengamalan ajaran Islam harus terpadu antara urusan pribadi dan masyarakat. Tidak ada di antara ajaran Islam yang hanya merupakan urusan pribadi dan tidak ada pula yang merupakan kepentingan masyarakat saja.

Ketiga, Akhlak atau etika. Menurut ajaran Islam meliputi hubungan dengan Allah (khaliq) dan hubungan dengan sesama makhluk, baik manusia maupun non manusia. Ajaran akhlak merupakan indikator kuat bahwa prinsip-prinsip ajaran Islam sudah mencakup semua aspek dan segi kehidupan manusia lahir maupun batin dan mencakup semua bentuk komunikasi, vertikal dan horizontal. Pendidikan akhlak yang berorientasi pada penanaman nilai luhur sebagai sifat dasar dalam menjamin hubungan dengan sesamanya sangat berkaitan dengan cara pandang dan watak dasar manusia. Untuk itulah akhlak merupakan pokok esensi ajaran islam di samping aqidah dan syariah karena akan terbina mental dan jiwa seseorang untuk memiliki hakikat kemanusiaan yang tinggi dengan akhlak dapat dilihat corak dan hakikat manusia yang sebenarnya; menurut ajaran Islam berdasarkan praktek Rasulullah, pendidikan akhlakul karimah (akhlak mulia) adalah faktor penting dalam membina suatu umat atau membangun suatu bangsa. Suatu pembangunan tidaklah ditentukan semata dengan faktor kredit dan investasi materiil. Betapapun melimpahnya kredit dan besarnya investasi.

Demikian pula pembangunan tidak mungkin berjalan hanya dengan kesenangan melontarkan fitnah pada lawan-lawan politik atau hanya mencari kesalahan orang lain. 
Inject, Interdisciplinary Journal of Communication, Vol. 1, No. 2, Desember 2016:165-180

Diperlukan dalam pembangunan adalah sikap keikhlasan, kejujuran, jiwa kemanusiaan yang tinggi. Sesuai antara ucapan dengan perbuatan, prestasi kerja, kedisiplinan, jiwa dedikasi dan selalu berorientasi kepada hari depan dan pembaharuan. Oleh karena itu program utama dan perjuangan pokok dari segala usaha ialah pembinaan akhlak mulia. Ia harus ditanamkan kepada seluruh lapisan dan tingkatan masyarakat, mulai dari tingkat atas sampai ke lapisan bawah, dari anak kecil sampai orang dewasa (Razak, 1989:37)

\section{Perkembangan Kepribadian Anak di Masyarakat}

Istilah kepribadian merupakan terjemahan dari Bahasa Inggris yaitu personality. Sedangkan istilah personality secara etimologi berasal dari Bahasa Latin person yang berarti kedok dan personare artinya menembus (Echols, 1996:426). Sedang menurut kamus Bahasa Indonesia (2002:895), bahwa kepribadian adalah sifat hakiki yang yang tercermin pada sikap seseorang yang membedakannya dari orang lain.

Pengertian kepribadian secara terminologi yang dikemukakan oleh para tokoh adalah Ahmad D. Marimba, kepribadian Muslim ialah kepribadian yang seluruh aspekaspeknya yakni baik tingkah laku luarnya kegiatan-kegiatan jiwanya, maupun filsafat hidupnya dan kepercayaannya menunjukkan pengabdian kepada Tuhan penyerahan diri kepadanya (Marimba, 1989:67). Kemudian Zakiah Daradjat menjelaskan tentang kepribadian yang sesungguhnya adalah abstrak maknawi sukar dilihat atau diketahui secara nyata, yang dapat diketahui adalah penampian atau bekasnya dalam segala segi dan aspek kehidupan. Misalnya dalam tindakannya, ucapan, caranya bergaul, berpakaian dan menghadapi masalah baik ringan ataupun berat. Kepribadian terpadu dapat mengjadapi segala persoalan dengan sehat dan wajar karena segala unsur dalam pribadinya bekerja seimbang dan serasi (Daradjat, 1995:52). Sedangkan Ngalim Purwanto mendefinisikan bahwa kepribadian adalah susunan dari sifat-sifat dan aspekaspek tingkah laku lainnya yang saling berhubungan di dalam suatu individu yang menyebabkan individu berbuat bertindak seperti apa yang dia lakukan dan menunjukkan ciri-ciri khas yang membedakan individu itu dengan individu lain. Termasuk di dalamnya sikap, kepercayaan, nilai-nilai dan cita-cita, pengetahuan, ketrampilan dan macam-macam gerak tubuh. Kepribadian berarti sifat hakiki individu yang tercermin pada sikap dan perbuatannya yang membedakan dirinya dari yang lain (Purwanto, 1996:156). 
Pada dasarnya aspek-aspek kepribadian itu dapat digolongkan dalam tiga hal, yaitu; (1) Aspek-aspek jasmaniah, meliputi tingkah laku luar yang mudah nampak dan ketahuan dari luar, misalnya cara-caranya berbuat, cara-caranya berbicara. (2) Aspekaspek kejiwaan meliputi aspek-aspek yang segera dapat dilihat dan ketahuan dari luar, misalnya cara-cara berfikir, bersikap, berpendirian, berpandangan. (3) Aspek-aspek kerohanian yang luhur, meliputi aspek-aspek kejiwaan yang lebih abstrak yaitu filsafat hidup dan kepercayaan. Ini meliputi sistem nilai yang telah meresap di dalam kepribadian itu, yang telah menjadi bagian dan mendarah daging dalam kepribadian itu yang mengarahkan dan memberi corak seluruh kehidupan individu (Marimba, 1989:67).

\section{Faktor-Faktor yang Mempengaruhi Kepribadian}

Pembentukan kepribadian dipengaruhi oleh beberapa faktor, baik hereditas (pembawaan) maupun miliu (lingkungan). Berikut adalah faktor-faktor yang mempengaruhi kepribadian, yaitu; (1) Fisik, yang dipandang mempengaruhi kepribadian adalah postur tubuh (langsing, pendek, gemuk atau tinggi) kecantikan, kesehatan, keutuhan, tubuh (utuh atau cacat) dan berfungsinya organ tubuh. Kondisi fisik yang berlainan itu menyebabkan sikap dan sifat-sifat serta temperamen yang berbeda-beda. (2) Intelegensi, yang tinggi atau normal biasanya mampu menyesuaikan diri dengan lingkungan secara wajar, sedangkan yang rendah biasanya sering mengalami hambatan dalam menyesuaikan diri dengan lingkungannya. (3) Keluarga, seorang anak yang dibesarkan dalam lingkungan yang harmonis dan agamis, maka kepribadian anak cenderung positif. Adapun anak yang dikembangkan dalam lingkungan keluarga yang adapun anak yang dikembangkan dalam lingkungan keluarga yang broken home, kenang harmonis, orang tua bersikap keras terhadap anak dan tidak memperhatikan nilai-nilai agama, amak perkembangan kepribadian cenderung akan mengalami, distorsi atau, mengalami kelainan dalam penyesuaian dirinya (maladjusment). (4) Teman sebaya atau peer group, melalui hubungan interpersonal dengan teman sebaya anak belajar menilai dirinya sendiri dan kedudukannya dalam kelompok. Bagi anak yang kurang mendapat kasih sayang, bimbingan keagamaan dan etika dari orang tuanya, biasanya kurang memiliki kemampuan selektif dalam memilih teman dan mudah terpengaruh oleh sifat dan perilaku kelompoknya. Proses terjadi setelah mulai masuk-masuk sekolah. Berdasarkan kenyataan dilapangan, ternyata tidak sedikit anak yang menjadi perokok 
Inject, Interdisciplinary Journal of Communication, Vol. 1, No. 2, Desember 2016:165-180

berat, peminum minuman keras, bergaul dengan bebas, karena pengaruh teman teman sebaya. (5) Kebudayaan, tradisi atau kebudayaan suatu masyarakat memberikan pengaruh terhadap kepribadian setiap anggotanya, baik menyangkut cara berpikir, bersikap pengaruh kebudayaan terhadap kepribadian dapat dilihat dari adanya perbedaan antara masyarakat modern dengan masyarakat primitif (Purwanto, 1996:157).

\section{Upaya Pengembangan Kepribadian Anak}

Perkembangan kepribadian menurut Ahmad D. Marimba mempunyai beberapa tahapan. Tahapan-tahapan itu ialah dengan cara melalui pembiasaan, pembentukan minat dan sikap dan pembentukan kerohanian yang luhur (Marimba, 1989:76). Pembiasaan dimaksudkan ialah mendisiplinkan anak kepada tugas-tugas pribadi yang harus diselesaikan anak secara mandiri dari mulai hal yang paling sederhana sampai yang sulit. Contohnya waktu mandi, membersihkan kamar tidur, kebiasaan berkata sopan sampai mengerjakan tugas-tugas sekolah, mengaji, ke Masjid dan lain-lain. Pendidikan pembiasaan ini memerlukan tenaga kepribadian yang lebih rendah karena banyak melibatkan aspek jasmaniah dari pada rohaniah sehingga bagi anak pembiasaan yang dilakukan kontinyu bukan menjadi beban bagi dirinya melainkan hal yang biasa.

Pola selanjutnya adalah pembentukan minat. Minat adalah kecendrungan jiwa kepada sesuatu pada umumnya disertai rasa senang akan sesuatu, dan bisa berkembang menjadi rasa kecintaan. Jika dalam masa perkembangan anak sudah didekatkan dengan keindahan, kebaikan, rasa sosial dan rasa ketuhanan akan menimbulkan rasa tertarik atau mempunyai kecendrungan pada hal-hal yang bersifat positif dalam kehidupannya kelak. Pendidikan sikap yang dimaksud ialah pendidikan moral dan watak yang harus dimiliki dan dijadikan kebiasaan oleh anak sejak dini sampai dewasa, sehingga anak tidak mempunyai akhlak atau sikap yang tercela. Terakhir dalam menanamkan kepercayaan agama atau rukun iman sejak dini. Hasilnya adalah kesadaran dan pengertian yang mendalam, segala yang dilakukan, diputuskan dan dilakun berdasarkan keyakinan dan dengan penuh rasa tanggung jawab dan pada akhirnya dari ketiga pola tersebut akan melahirkan anak dengan kepribadian yang sehat. 
Imam Subqi, Pola Komunikasi Keagamaan Dalam Membentuk...

\section{Pembinaan Agama Islam dengan Perkembangan Kepribadian Anak}

Pembentukan kepribadian itu berlangsung secara berangsur-angsur, bukan hal yang sekali jadi, melainkan sesuatu yang berkembang. Oleh karena itu pembentukan kepribadian merupakan suatu proses. Kepribadian terbentuk melalui semua pengalaman dan nilai-nilai yang diserap oleh anak, terutama pada masa perkembangannya. Apabila nilai-nilai agama banyak masuk ke dalam pembentukan kepribadian seseorang, maka tingkah laku orang tersebut akan banyak diarahkan dan dikendalikan oleh nilai-nilai agama. Disinilah letak pentingnya pengalaman dan pendidikan agama pada masa pertumbuhan dan perkembangan (Daradjat, 2001:63). Hal ini didukung oleh teori mengenai kepribadian yang berpendapat bahwa tipe kepribadian ditentukan oleh aspek biologis seperti bentuk tubuh, kualitas sosial dan aspek psikologis yang menyangkut unsur kejiwaan yang dimiliki oleh seseorang. Kepribadian seseorang dapat dibentuk melalui bimbingan dari luar berupa pendidikan maupun pembinaan karena manusia mengalami proses belajar dalam hidupnya. Kenyataan ini memberikan peluang bagi usaha pendidian maupun pembinaan dalam pembinaan kepribadian (Jalaludin, 2002:91). Selanjutnya dari kepribadian tersebut mampu dipertahankan sebagai kebiasaan yang tidak dapat dipengaruhi oleh sikap dan tingkah laku orang lain yang bertentangan dengan apa yang dimiliki. Ciri khas tersebut hanya mampu dipertahankan jika sudah terbentuk dalam waktu yang lama atau mempunyai latar belakang yang lama dan tentunya dalam lingkungan yang baik terutama dari lingkungan keluarga.

Kepribadian secara utuh hanya mungkin dibentuk melalui pengaruh lingkungan khususnya pendidikan dengan sasaran mempunyai iman yang kuat dan akhlak yang mulia, dengan pemikiran bahwa iman adalah pengatur tingkah laku sedangkan akhlak adalah perwujudan dari iman yang berhubungan dengan sikap dan prilaku sehari-hari. Menurut Asghar Ali Engineer (1999:20) jika pembinaan agama Islam benar-benar berhasil maka anak akan mempunyai kepribadian dengan ciri-ciri berikut (1) Selalu menempuh jalan hidup yang didasarkan didikan ketuhanan dengan melaksanakan ibadah. (2) Senantiasa berpedoman kepada petunjuk Allah. (3) Merasa memperoleh kekuatan untuk menyerukan dan berbuat benar dan menyampaikan kebenaran kepada orang lain. (4) Memiliki keteguhan hati. (5) Mempunyai kemampuan yang kuat dan tegas. (6) Tabah, (7) Memiliki kelapangan dan ketentraman hati.(8) Mengetahui tujuan hidup. (9) Tobat jika melakukan kesalahan. 
Inject, Interdisciplinary Journal of Communication, Vol. 1, No. 2, Desember 2016:165-180

Menurut Jalaluddin (2002:175) dalam buku Psikologi Agama, kepribadian juga memiliki dinamika yang unsurnya secara aktif ikut mempengaruhi aktivitas seseorang. Unsur-unsur tersebut ialah (1) Energi rohaniah (psychis energy) yang berfungsi pengatur aktivitas rohaniah seperti berpikir, mengingat, mengamati dan sebagainya. (2) Naluri, yang berfungsi sebagai pengatur kebutuhan primer seperti makan, minum dan seks. Sumber naluri adalah kebutuhan jasmaniah dan gerak hati. Berbeda dengan energi rohaniah, maka naluri mempunyai sumber pendorong, maksud dan tujuan. (3) Ego (aku sadar) yang berfungsi untuk meredakan ketegangan dalam diri dengan cara melakukan aktivitas penyesuaian dorongan-dorongan yang ada dengan kenyataan obyektif (realitas). Ego meliki kesadaran untuk menyelaraskan dorongan yang baik yang baik dan buruk hingga tidak terjadi kegelisahan atau ketegangan batin. (4) Super ego yang berfungsi sebagai ganjaran batin baik berupa penghargaan (rasa puas, senang, berhasil) maupun berupa hukuman (rasa bersalah, berdosa, menyesal). Penghargaan batin diperankan oleh ego-ideal, sedangkan hukuman batin dillakukan oleh hati nurani.

Berkaitan dengan tingkah laku, maka kepribadian manusia sebenarnya telah diatur semacam sistem kerja yang menyelaraskan tingkah laku manusia agar tercapai ketentraman dalam batinnya. Secara fitrah manusia terdorong untuk melakukan sesuatu yang baik, benar dan indah. Namun terkadang naluri mendorong manusia untuk segera memenuhi kebutuhannya yang bertentangan dengan realita yang ada. Misalnya dorongan untuk makan ingin dipenuhi, tetapi makanan tidak ada (realitas), maka timbul dorongan untuk mencuri. Jika perbuatan itu dilakukan, maka Ego (aku sadar) akan merasa bersalah, karena mendapat hukuman dari Ego-ideal (norma agama) sebaliknya jika dorongan untuk mencuri tidak dilaksanakan maka Ego akan memperoleh penghargaan dari hati nurani. Pemenuhan dorongan pertama akan menyebabkan terjadi kegelisahan pada Ego, sedangkan pemenuhan dorongan kedua akan menjadikan Ego tenteram. Dengan demikian, kemampuan Ego untuk menahan diri tergantung dari pembentukan Ego-ideal.

\section{Simpulan}

Pembinaan agama dengan pembinaan mental diawali sejak anak dilahirkan ke dunia, mulailah ia menerima pendidikan dan perlakuan. Mula-mula dari ibu bapaknya, kemudian dari anggota keluarga yang lain, semuanya itu ikut memberikan dasar-dasar 
pembentukan kepribadiannya. Pembinaan dan pertumbuhan kepribadian itu kemudian ditambah dan disempurnakan oleh sekolah. Pendidikan agama pada pada masa anakanak dilakukan dengan metode pembiasaan kepada tingkah laku dan akhlak yang diajarkan oleh agama. Dalam menumbuhkan kebiasaan akhlak karimah seperti jujur, adil, sopan dan sebagainya orang tua harus memberikan contoh, karena anak ini mempunyai sifat meniru apa yang dia lihat. Apabila anak telah terbiasa berbuat baik maka akan tertanamlah rasa itu ke dalam jiwanya dan menjadi salah satu unsur kepribadiannya. Demikian pula nilai-nilai agama dan kaidah-kaidah sosial yang lain, sedikit demi sedikit masuk dalam perkembangan mentalnya.

Apabila pembinaan agama itu tidak diberikan kepada anak sejak kecil, maka akan sukarlah baginya untuk menerima apabila ia dewasa, karena dalam kepribadiannya yang terbentuk sejak kecil itu tidak terdapat unsur-unsur agama. Jika dalam kepribadian itu tidak ada nilai-nilai agama, akan mudahlah orang melakukan segala sesuatu menurut dorongan dan keinginan jiwanya tanpa mengindahkan kepentingan dan hak orang lain. Ia selalu didesak oleh keinginan dan kebutuhan yang pada dasarnya tidak mengenal batas-batas, hukum dan norma. Tetapi jika dalam kepribadiannya tertanam nilai-nilai agama maka segala keinginan dan kebutuhannya akan dipenuhi dengan cara yang tidak melanggar hukum, karena jika ia melanggar akan goncang jiwanya karena tindakannya tidak sesuai dengan kepribadiannya. Maka pembinaan agama pada anak benar-benar akan menjadi kontrol pribadi terhadap sikap dan perbuatannya.

\section{Daftar Pustaka}

Anshori, Endang Syaifuddin. 1989. Kuliah Al-Islam. Yogyakarta: Rajawali.

Arief, Armai. 2002. Pengantar Ilmu dan Metodologi Pendidikan Islam. Jakarta: Ciputat Pers. Asrohah, Harun. 2001. Sejarah Pendidikan Islam. Jakarta: Logos Wacana Ilmu.

Daradjat, Zakiah. 1996. Ilmu Jiwa Agama. Jakarta: Bulan Bintang. 2001. Kesehatan Mental. Jakarta: Gunung Agung. 1995. Pendidikan Islam dalam Keluarga dan Sekolah. Jakarta: Ruhama.

Departemen Pendidikan dan Kebudayaan. 2002. Kamus Bahasa Indonesia. Jakarta: Balai Pustaka.

Echols, John M. dan Hassan Shadily. 1996. Kamus Inggris Indonesia. Jakarta: Gramedia. Ismail SM. Et. All. 2001. Paradigma Pendidikan Islam. Yogyakarta: Pustaka Pelajar. 
Inject, Interdisciplinary Journal of Communication, Vol. 1, No. 2, Desember 2016:165-180

Jalaluddin. 2002. Psikologi Agama. Jakarta: Grafindo Persada.

Kadir, Muslim A. 2002. Ilmu Islam Terapan. Yogyakarta: Pustaka Pelajar.

Kahmad, Dadang. 2000. Metode Penelitian Agama. Bandung: Pustaka Setia.

Marimba, Ahmad D. 1989. Pengantar Filsafat Pendidikan Islam. Bandung: Al-Ma'arif.

Matdawam, M. Noor. 1995. Aqidah dari Ilmu Pengetahuan dalam Lintasan Sejarah Dinamika Budaya Manusia. Yogyakarta: Yayasan Bina Karier LPSBIP.

Mukhtar, Maksum. 2001. Madrasah Sejarah dan Perkembangannya. Jakarta: Logos Wacana Ilmu.

Nata, Abuddin. 1997. Filsafat Pendidikan Islam. Jakarta: Logos Wacana Ilmu.

Purwanto, Ngalim. 1996. Psikologi Pendidikan. Bandung: Remaja Rosda Karya.

Razak, Nasruddin. 1998. Dienul Islam. Bandung: Al-Ma'arief.

Shaleh, Abdul Rachman. 2000. Pendidikan Agama dan Keagamaan, Misi Visi dan Aksi. Jakarta: Gemawindu Panca Perkasa.

Soetopo, Hendyat dan Wanty Soemanto. 1982. Pembinaan dan Pengembangan Kurikulum, Jakarta: Bina Aksara.

Syah, Muhibbin. 2000. Psikologi Pendidikan Dengan Pendekatan Baru. Bandung: Remaja Rosda Karya.

Tafsir, Ahmad. 1995. Metodologi Pengajaran Agama Islam. Bandung: Remaja Rosda Karya.

Ulwan, Abdullah Nashih. 1999. Pendidikan Anak Dalam Islam. Jakarta: Pustaka Amani.

Usman, Basyiruddin. 2002. Metodologi Pembelajaran Agama Islam. Jakarta: Ciputat Pers.

Wahjoetomo. 1979. Pendidikan Alternatif Masa Depan. Jakarta: Gema Insani Press.

Zuhaili, Muhammad. 2002. Pentingnya Pendidikan Islam Sejak Dini. Jakarta: AH. Ba'adillah Press.

Zuhairini. 2007. Sejarah Pendidikan Islam. Jakarta: Bumi Aksara. 